\title{
Sustainability of Excavation Soil and Red Brick Waste in Rammed Earth
}

\author{
Mostafa Shaaban \\ Department of Civil Engineering, Giza Higher Institute for Engineering and Technology, Egypt
}

Received January 2, 2021; Revised March 30, 2021; Accepted April 18, 2021

\section{Cite This Paper in the following Citation Styles}

(a): [1] Mostafa Shaaban, "Sustainability of Excavation Soil and Red Brick Waste in Rammed Earth," Civil Engineering and Architecture, Vol. 9, No. 3, pp. 789-798, 2021. DOI: 10.13189/cea.2021.090320.

(b): Mostafa Shaaban (2021). Sustainability of Excavation Soil and Red Brick Waste in Rammed Earth. Civil Engineering and Architecture, 9(3), 789-798. DOI: 10.13189/cea.2021.090320.

Copyright $\mathrm{C} 2021$ by authors, all rights reserved. Authors agree that this article remains permanently open access under the terms of the Creative Commons Attribution License 4.0 International License

\begin{abstract}
Sustainable construction is an urgent theme in both industrial and developing countries where the construction sector consumes $36 \%$ of worldwide energy usage and $40 \%$ of the natural resources. Moreover, it causes a hug adverse impact on the environment. One of the major practices to achieve sustainability in construction sector is the use of waste and recycled materials as building materials. The use of waste reduces the consumption of natural resources, energy consumption and carbon emissions. This study is carried out on three types of waste and by-product materials; excavation waste, crushed red brick, and fly ash (FA) which emits from coal-fired thermal plants. The study aims to assess these materials to produce rammed earth as sustainable solution reduces resource consumption, energy consumption, and the environmental pollutants caused by building activities and industrial waste. In order to achieve that, five FA levels $0 \%, 5 \%, 10 \%$, $15 \%$, and $20 \%$ were mixed with excavation waste of natural soil, and crushed red brick to prepare five rammed earth mixtures. The samples were tested for compressive strength, dry shrinkage, erosion resistance, and microstructure analysis using the scanning electron microscope. The obtained results show that the aforementioned materials can be utilized to produce rammed earth comply with the standard requirements. Also, the observed results indicate that the better properties were measured for mixture prepared using $20 \%$ fly ash.
\end{abstract}

Keywords Sustainable Building Materials, Solid Waste, Rammed Earth, Excavation Soil, Red Bricks Waste

\section{Introduction}

The Construction industry consumes about $40 \%$ of natural extracted resources [1] and consumes $40 \%$ of the energy in the developed countries [2]. Also, the construction industry sector is responsible for $30 \%$ of greenhouse gases [3] and $9 \mathrm{Gt} /$ annum of waste globally [4]. Bricks, tiles, and concrete waste represent $50 \%$ of the total construction and demolition $[5,6]$. Therefore, it is important to find alternative building materials to minimize resource consumption (energy, land, water, materials), and to maximize both resource efficiency and protection of the natural environment. These targets can be achieved by expanding the use of sustainable and green building materials, as they provide better gains in the long run $[7,8]$. The use of sustainable materials, such as the earthen materials, and demolition waste materials appears to be a viable solution not only to the pollution problem but also an economical option [9, 10]. Moreover, transportation $\mathrm{CO}_{2}$ emissions can be reduced if on-site excavation earth and construction demolition waste are used as a building material. Adopting the utilization of any sustainable material depends on many criteria such as the availability of this material and its specifications [11].

Several studies describe the benefits gains with reusing excavated soil at the construction site. Chittoori et al. [12] described the cost and environmental benefits of reusing excavated soil reduce the material management costs and climate impact by $85 \%$. Eras et al. [13] showed that it was possible to relocate and reuse $44 \%$ of the excavated materials and hence reduce earthwork and transports to landfills as well as the use of quarry materials. Voit and Zimmermann [14] investigated the mechanically relevant 
parameters of fresh and hardened concrete using excavated materials as aggregates. Priyadharshinia et al. [15] studied reusing excavated soil as an alternative to river sand in the production of mortar. Flow, dry density, compressive strength, water absorption, and dry shrinkage tests were performed to understand the effect of washing treatment on excavation soil-based cement mortar; results concluded that washing treatment is effective in the use of excavated soil as fine aggregate. Anjaneya Dixit [16] demonstrated the utilization of marine clay obtained from excavation works as a substitute to quartz filler in ultra-high performance concrete. This study shows waste marine clay as a viable alternative to costly and carcinogenic quartz powder and hence, provides a new approach for sustainable UHPC.

Other studies focused on the use of construction waste as an alternative to aggregate or cement in the manufacture of concrete and mortars. Clay bricks powder have pozzolanic properties so it suitable as a partial substitute for cement in concrete production $[17,18]$. The manufacturing of clay brick implies exposure to elevated temperatures, ranging from 600 to $1000^{\circ} \mathrm{C}$, that causes a change in the structure of its silicates to an amorphous compound that reacts with lime at room temperature [19,20,21].Rammed earth is considered a sustainable solution due to its low carbon footprint, little materials treatment process, high recyclability, long service life [22] and low embodied energy where stabilized earth's embodied energy is 0.7 $\mathrm{Mj} / \mathrm{kg}$ while cement's embodied energy is $5.6 \mathrm{Mj} / \mathrm{kg}$ [23]. In addition, earth walls have a good thermal behavior due to their high mass and can contribute, with proper natural ventilation strategies, to the indoor building comfort providing high thermal inertia to deal with the day-night temperature changes [24,25].Besides the environmental benefits of the rammed earth construction technique, it presents social and economic features [26] especially in isolated area and developing countries where material costs exceed the labor costs, where other building materials and construction technologies may be not available [27] while a local unskilled labor force can be readily employed. Historically, raw earth is the earliest and most widespread building materials. Although, the use of Portland cement since 1824 , and steel have pushed rammed earth away from conventional construction [28], the renewed interest in raw earth as a building material stems from several features such as low cost, self-build practice, and keeping of resources [29]. Rammed earth is considered a homogeneous construction [30] composed of sand, clay, silt, and gravel mixed with low moisture content, and compacted inside temporary formwork [31].

Rauch [32] reported that the addition of gravels or pebbles in rammed earth mix enhances its surface durability. Ciancio et al. [33] reported that the optimal moisture content depends on the content of clay and silt and usually around $10 \%$ of the dry weight. Based on the type of binder, there are two types of rammed earth; non-stabilized rammed earth where the only used binder is clay, and stabilized rammed earth where other binders can be added, such as lime, cement, gypsum, and chemical solutions such as silicates [34].Stabilization of rammed earth improves its mechanical performance, erosion resistance, wet strength, and durability $[35,36]$, and the addition of short fibers improve the stabilization of rammed earth against shrinkage [37]. Stabilization of rammed earth requires less cement (typically $6-8 \%$ by weight) $[38,39]$, which still remains the principal contributor to embodied energy and greenhouse gas emissions [40].Moreover, the recyclability of the material after its service time is also debated [32]. Efforts to reduce cement use further through substitution with fly ash, ground granulated blast-furnace slag [41], and/or fibers [42]. To enhance the binding and tensile strength of rammed earth in seismic areas, fibers are added [43].

\section{Research Significance}

The importance of this study is due to the fact that it aims to utilize various wastes such as excavation waste, red brick waste, and fly ash as building materials used for example but not limited to produce rammed earth. By using these materials, resource efficiency can be increased, energy-reduced, and the environment protected from pollution by reducing solid waste from industrial and construction activities, as well as reducing greenhouse gases emissions. Evaluation of properties of rammed earth produced using these waste were presented in this study.

\section{Experimental Program}

\subsection{Materials}

\subsubsection{Natural soil}

The used natural soil shown in Figure 1 was produced from excavation work on-site. The particle size distribution of this soil is shown in Figure 2.The properties of the used natural soil are listed in Table 1.

\subsubsection{Industrial Waste}

Two types of solid industrial waste were used in this study:

- Crushed red brick: The remnants of the red brick were crushed to graded particles containing some powder as shown in Figure 2. The grading curve of crushed red bricks is shown in Figure 3.Properties of crushed red bricks are presented in Table 1.

- Fly ash: It is a by-product emits from coal-fired thermal plants and it was used here to stabilize the soil with five levels; $0 \%, 5 \%, 10 \%, 15 \%$, and $20 \%$ per dry soil weight. The chemical constituents of fly ash are listed in Table 2.

\subsubsection{Mixing Water}

Portable water complies with ASTM 
C1602/C1602M-18 [44] was used in soil mixing with the optimum moisture content.

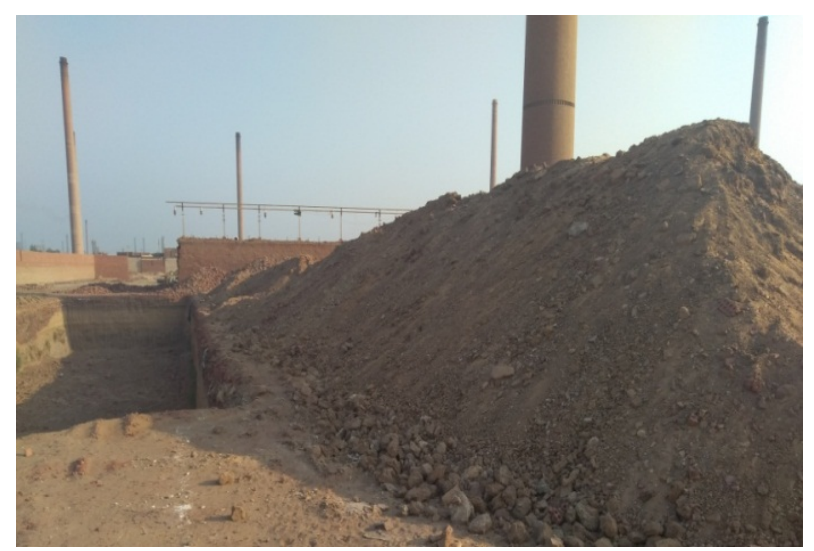

Figure 1. Excavation Soil Waste

Table 1. Properties of Natural soil and crushed red brick

\begin{tabular}{|c|c|c|}
\hline Property & Natural Soil & Crushed Red Bricks \\
\hline Specific gravity & 2.6 & 2.05 \\
\hline $\begin{array}{c}\text { Dry unit weight } \mathrm{kg} / \mathrm{m}^{3} \\
\mathrm{k}\left(\mathrm{kg} / \mathrm{m}^{3}\right)\end{array}$ & 1350 & $\mathbf{1 1 9 5}$ \\
\hline Absorption \% & - & $14 \%$ \\
\hline Liquid limit (LL) & 31.5 & - \\
\hline Plastic limit (PL) & 18.5 & - \\
\hline Plasticity index (PI) & 13.0 & - \\
\hline
\end{tabular}

Table 2. Chemical composition of Fly ash

\begin{tabular}{|c|c|}
\hline Compound & Content \% wt. \\
\hline $\mathrm{SiO}_{2}$ & 59 \\
\hline $\mathrm{Al}_{2} \mathrm{O}_{3}$ & 21 \\
\hline $\mathrm{Fe}_{2} \mathrm{O}_{3}$ & 3.7 \\
\hline $\mathrm{CaO}$ & 6.9 \\
\hline $\mathrm{MgO}$ & 1.4 \\
\hline $\mathrm{SO}_{3}$ & 1.0 \\
\hline $\mathrm{K}_{2} \mathrm{O}$ & 0.9 \\
\hline
\end{tabular}

\subsection{Soil Mixtures Proportions}

To prepare the studied mixtures, a constant proportion of the natural soil and crushed red bricks was mixed with five levels of fly ash $0 \%, 5 \%, 10 \%, 15$, and $20 \%$.The water to dry materials ratio was constant for all mixtures and equal to 0.15 .The mix proportions for all mixtures are presented in Table 3.

Table 3. Mix proportions $\left(\mathrm{kg} / \mathrm{m}^{3}\right)$

\begin{tabular}{|c|c|c|c|c|c|}
\hline $\begin{array}{c}\text { Mix } \\
\text { designation }\end{array}$ & $\begin{array}{c}\text { Natural } \\
\text { soil (Kg) }\end{array}$ & $\begin{array}{c}\text { Crushed } \\
\text { bricks } \\
(\mathrm{Kg})\end{array}$ & FA \% & $\begin{array}{c}\text { FA } \\
(\mathrm{Kg})\end{array}$ & $\begin{array}{c}\text { Water } \\
(\mathrm{Kg})\end{array}$ \\
\hline M0 & $\mathbf{7 5 0}$ & 942 & $0 \%$ & 0 & 254 \\
\hline M5 & $\mathbf{7 5 0}$ & 942 & $5 \%$ & 85 & $\mathbf{2 5 4}$ \\
\hline M10 & $\mathbf{7 5 0}$ & 942 & $10 \%$ & 170 & $\mathbf{2 5 4}$ \\
\hline M15 & $\mathbf{7 5 0}$ & 942 & $15 \%$ & 255 & 254 \\
\hline M20 & $\mathbf{7 5 0}$ & 942 & $20 \%$ & 340 & 254 \\
\hline
\end{tabular}

\subsection{Sample Preparation and Testing}

Natural soil and crushed brick were mixed in a dry state then fly ash was added and remixed again. Water was sprinkled uniformly with continuous stirring to obtain a homogeneous mixture. Then, the specimens were formed in three layers, each layer rammed by freely lowering the rammer from a height of $30 \mathrm{~cm}$ to the surface of the mixture. The specimens were prepared for the next tests:

- The compressive strength: Compressive strength of the compacted soil test was carried out on cubic specimens of $150 * 150 * 150 \mathrm{~mm}$ as shown in Figure 4 .

- The microstructure of mixtures: The scanning electron microscopy (SEM) analysis was used to study the microstructure of samples at 28 days of curing. For observation of SEM, pieces of specimens were cut and ground to expose a fresh surface then coated with gold in a sputter coater to obtain clear SEM images.

- Linear Shrinkage: The test of linear shrinkage was carried out on specimens of $500 \mathrm{~mm} \times 100 \mathrm{~mm} \times 100$ $\mathrm{mm}$ according to Amsler method described in the PN-B-06714-23 standard [45].

- Erosion Resistance: To evaluate the rammed earth resist to weathering the rammed earth specimens were subjected to repeated cycles of wetting and drying in accordance ASTM D559 / D559M-15 [46]. 


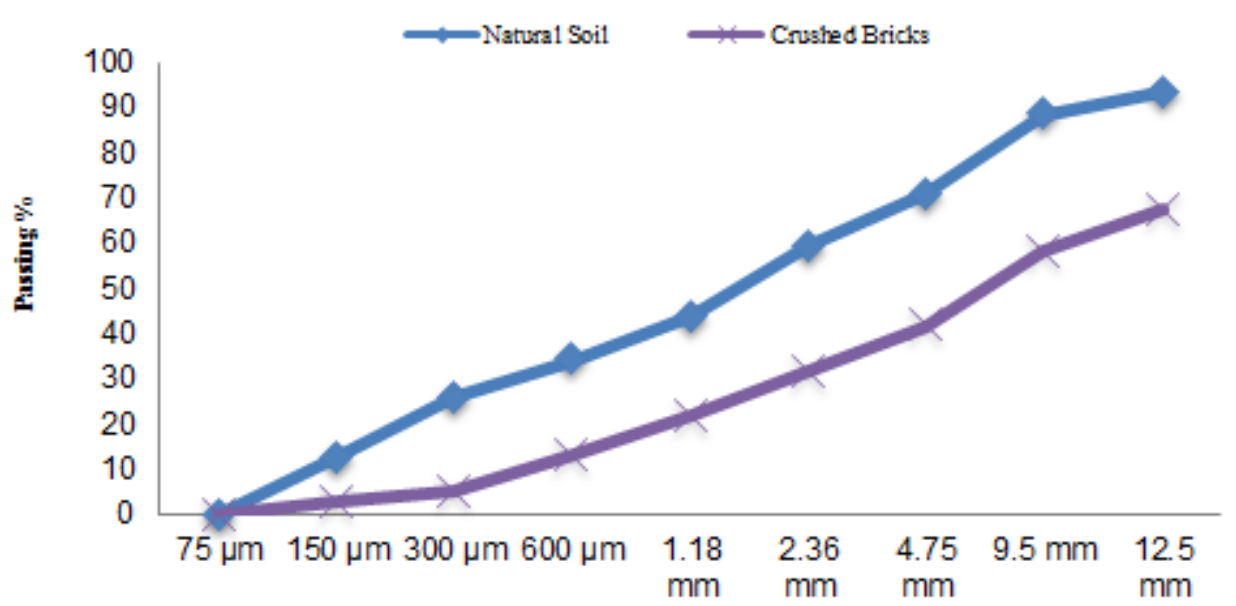

Figure 2. Particle Size Distribution of the natural soil and crushed red bricks

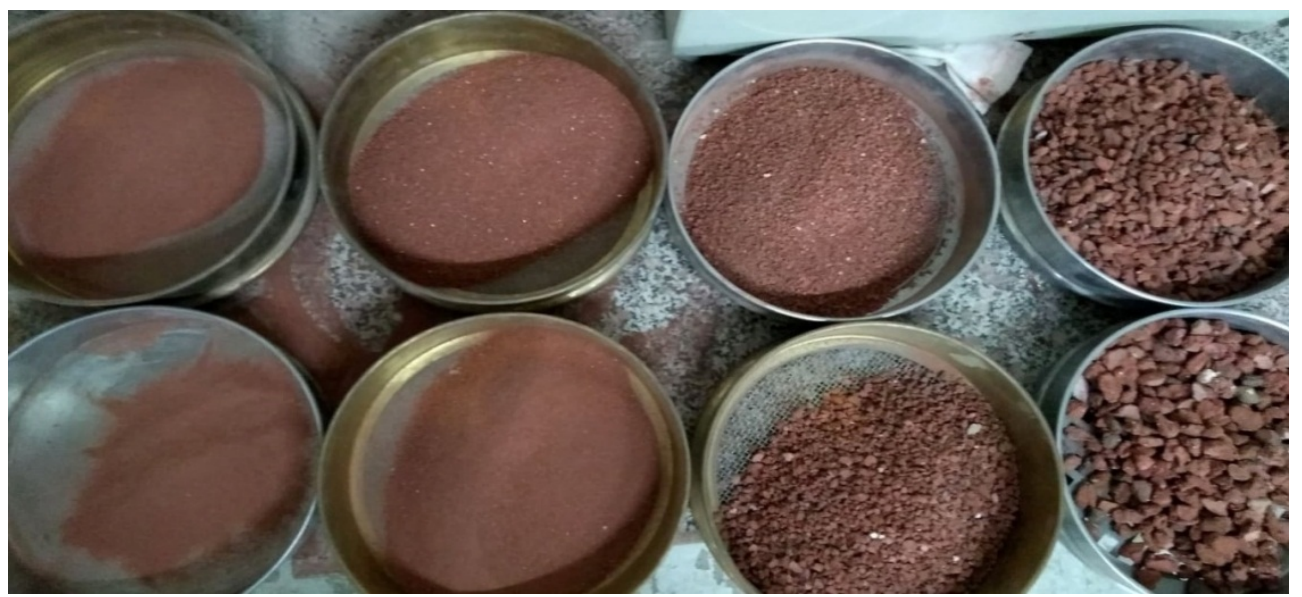

Figure 3. Crushed red bricks

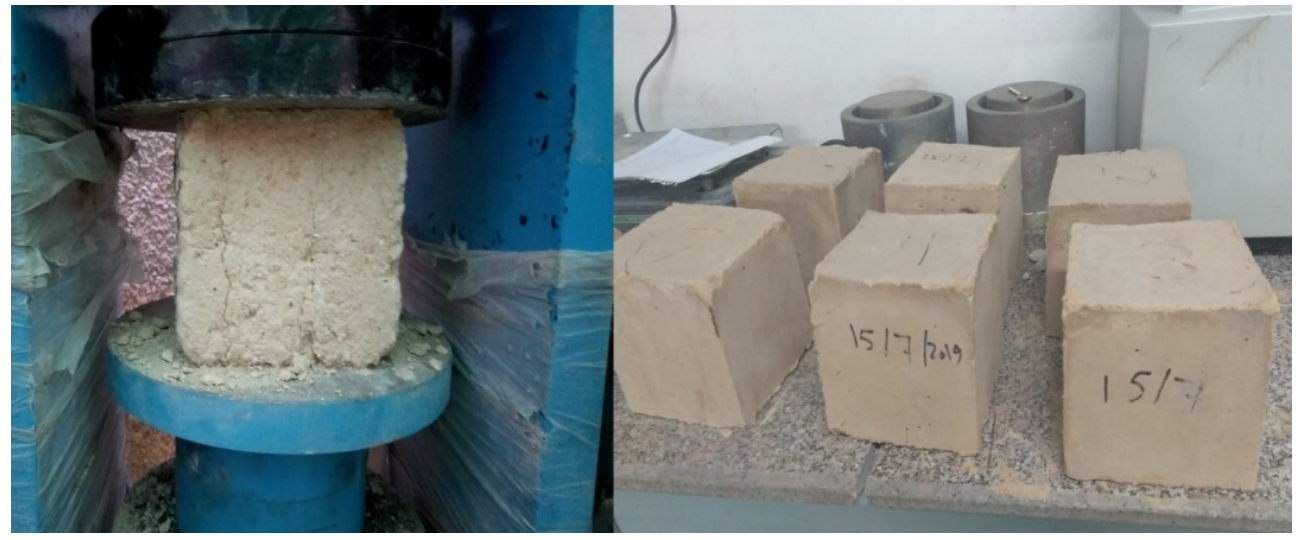

Figure 4. Compressive Strength Specimens

\section{Results and Discussion}

\subsection{Compressive Strength}

Figure 5 presents the compressive strength results of all investigated mixtures. The compressive strength values are acceptable since the minimum compressive strength requirements is $1.35 \mathrm{MPa}$ [47]. These values are related to several factors such as; the compaction process used since compacting the soil where the higher density obtained by compaction significantly increases the compressive strength [48], the presence of coarse crushed bricks, the filler and pozzolanic effect of superfine particles of crushed bricks [49], and the pozzolanic reactivity of fly ash [50].These results show that there is an increase in compressive strength as the fly ash content increase. For 
example, the mixture contains $5 \%$ fly ash have compressive strength higher than that of $0 \%$ fly ash with $63 \%, 48.25$, and $51.5 \%$ at 7,14 , and 28 days respectively. At $10 \%$ fly ash the compressive strengths are $67.7 \%, 57 \%$, and $60 \%$ more than that of $0 \%$ fly ash at ages of 7,14 , and 28 days respectively. Moreover, using $15 \%$ of fly ash leads to strength increase with $70 \%, 59 \%$, and $63 \%$ at 7,14 , and 28 days respectively. Fly ash content of $20 \%$ leads to compressive strength higher than that of $0 \%$ fly ash with percentages of $73 \%, 65 \%$, and $68 \%$ at $7,14,28$ days respectively.

\subsection{Linear Shrinkage}

The linear shrinkage of the investigated mixtures was carried out on specimens at ages of 7, 28, and 56 days. The obtained results of this test are shown in Figure 6.These results show that the mixture without stabilizer (i.e. $\mathrm{FA}=0 \%$ ) have the higher linear shrinkage at the different ages where as the shrinkage increases overtime from $0.19 \%$ to $0.28 \%$ at 7 and 28 days respectively and reach up to $0.39 \%$ at 56 days. Figure 6 indicates that the linear shrinkage decreases with increasing fly ash content at all ages. For example, the linear shrinkage at 7 days of mixtures containing $5 \%, 10 \%, 15 \%$, and $20 \%$ fly ash were lower than that of mixture without fly ash by $21 \%, 31.6 \%, 47.4 \%$, and $58 \%$ respectively. Otherwise, the linear shrinkage increases with time for all mixtures containing fly ash, this increase ranges between $46.6 \%$ and $50 \%$ when comparing shrinkage at 28 days with shrinkage at 7 days. At 56 days, the linear shrinkage increases with more than $100 \%$ compared to shrinkage at 7 days. Generally, it noticed that the most linear shrinkage occurs in the first seven days, and this could be due to the evaporation of free capillary water through the interconnected pores. Also, the investigated specimens achieved linear shrinkage between $0.08 \%$ and $0.43 \%$ which was less than the requirement for rammed earth $0.5 \%$ according to NZS 4298:1998 [51]. At the later ages, the pore size reduced due to the pozzolanic reaction of flay ash and super fine red bricks powder moreover all water consumed in this reaction. Consequently the linear shrinkage rate reduced at later ages and as the fly ash level increased. Beside the free water content, the shrinkage strongly depends on the presence of clay in the soil [52]. The presence of fine and coarse crushed bricks particles reduces the dry shrinkage as a result of reducing the clay amount and restricting the volumetric changes.

\subsection{Erosion Resistance}

In this work, the durability was evaluated by exposing the specimens to successive three cycles of wetting and drying then the specimens were tested for compressive strength. The obtained results of the residual compressive strength and reduction percentages are shown in Figure 7 and Figure 8 respectively.

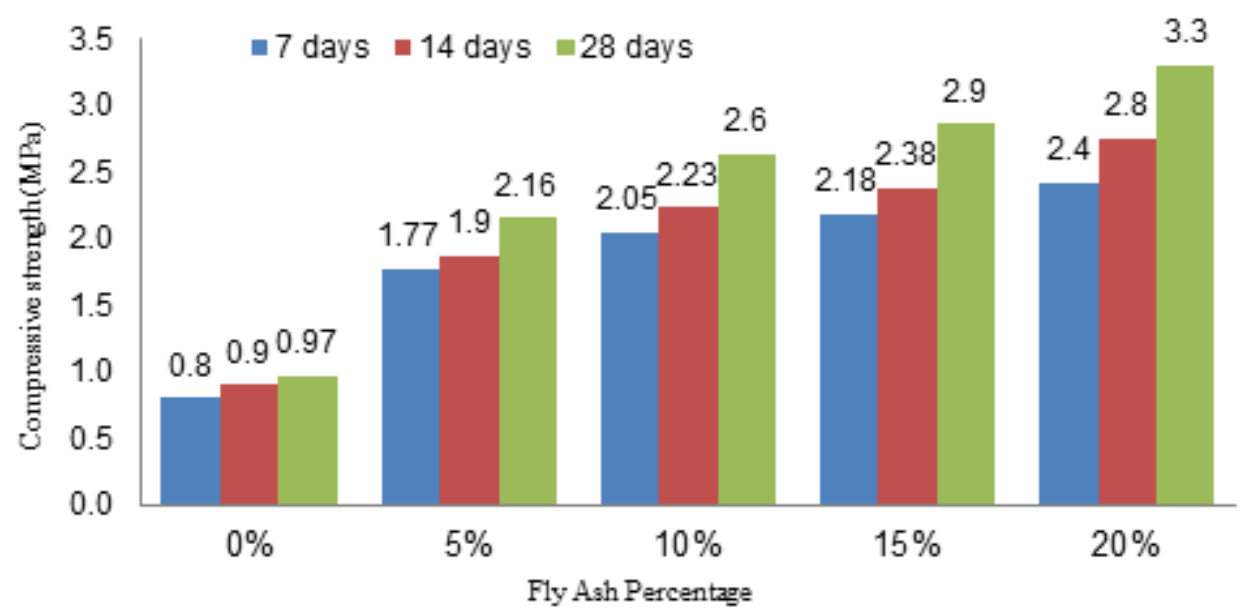

Figure 5. Compressive strength at 7,14 , and 28 days 


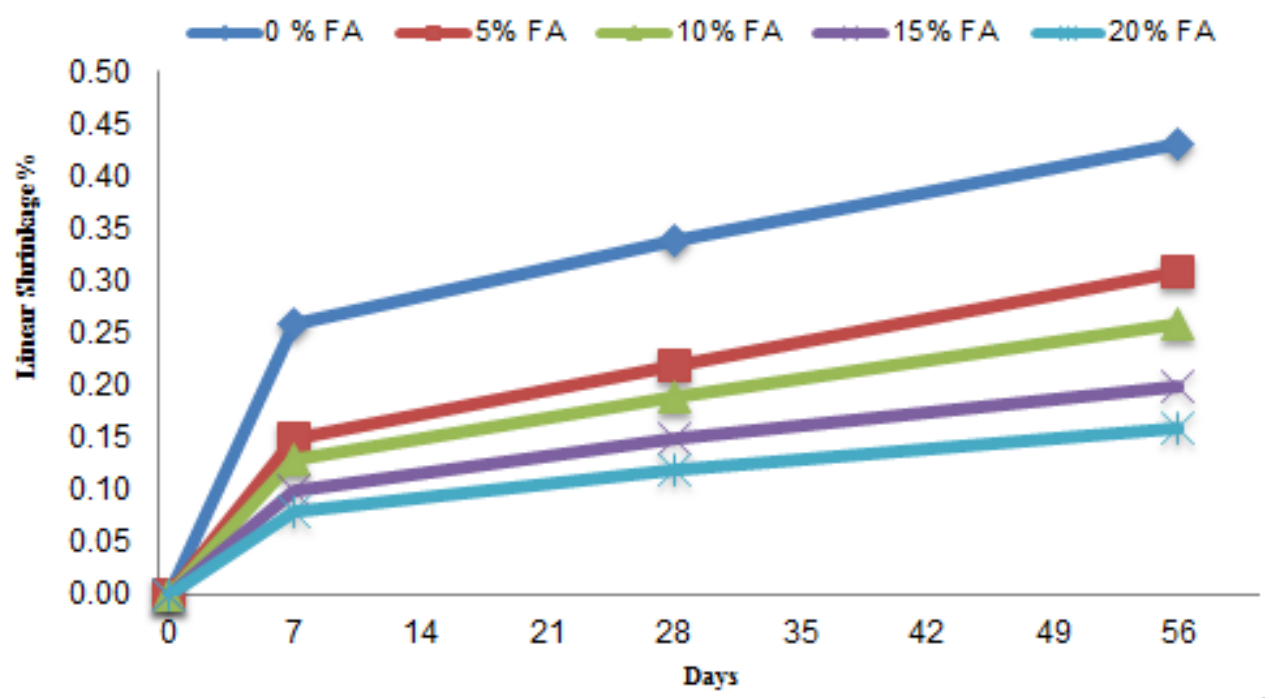

Figure 6. Linear dry shrinkage Percentage

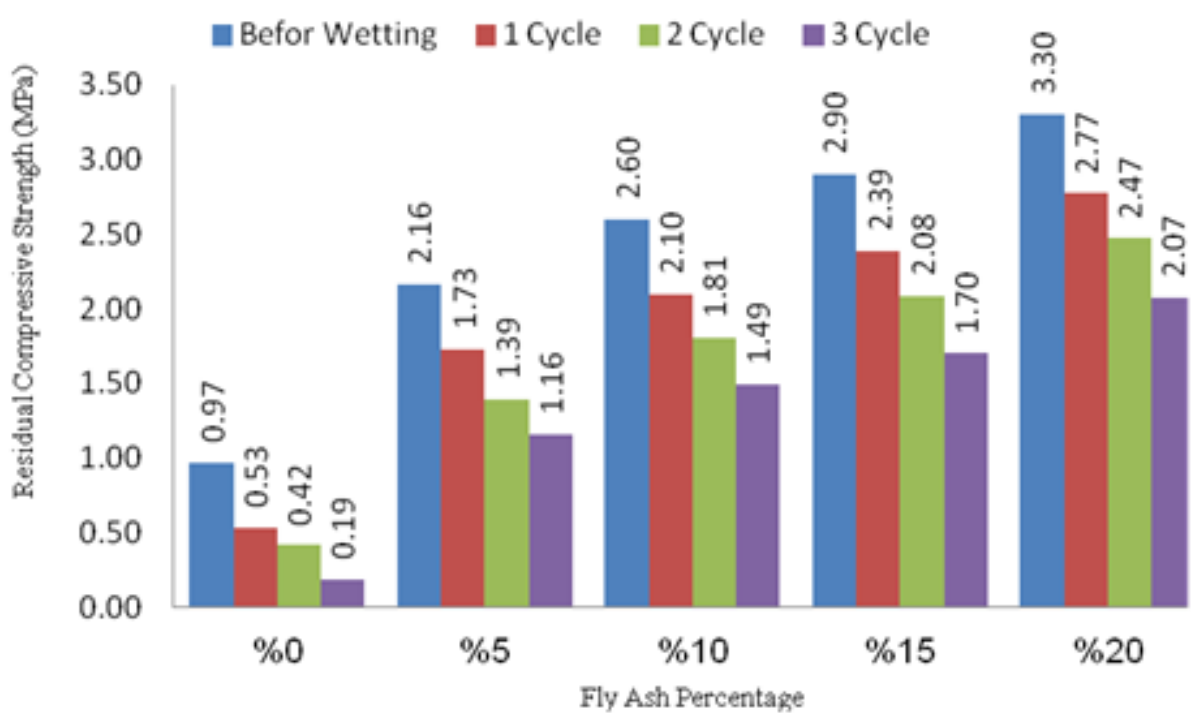

Figure 7. Residual Compressive strength after 1,2, and 3 Cycles of Wetting and Draying

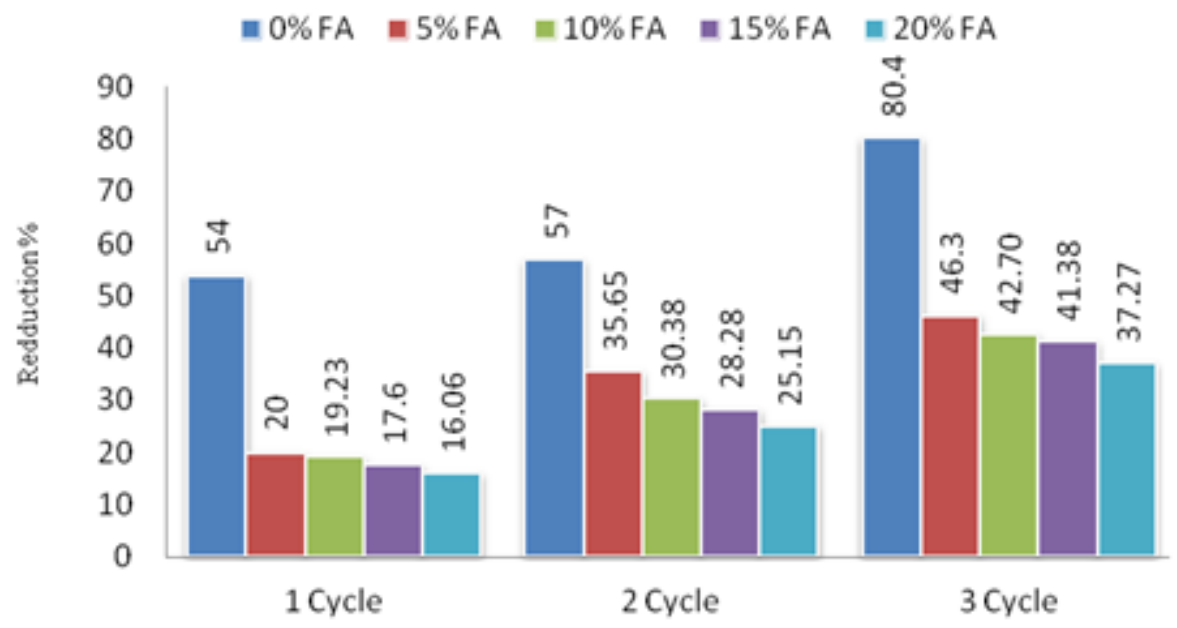

Figure 8. Reduction \% of Compressive strength after alternate Cycles of Wetting and Drying 
It noticed that there are severe decreases in the compressive strength values of the mixture without stabilizer $(0 \%$ FA) after all cycles. The residual compressive strength of this mixture was $0.55 \mathrm{MPa}$ after the first cycle which decreases to $0.42 \mathrm{MPa}$ after the second cycle as well as the residual compressive strength reaches to $0.19 \mathrm{Mpa}$ after the third cycle. This means that the compressive strength reduced by $54 \%, 57 \%$, and $80.4 \%$ after the first, second, and third cycle respectively as shown in Figure 8. This reduction of strength is due to absence of a binder that binds the grains of soil and crushed bricks apart from the weak role played by red brick powder as a binder. Also the recorded results show that the residual compressive strength increases as the fly ash level increase, for example the residual compressive strength of mixtures containing $5 \%, 10 \%, 15 \%$, and $20 \% \mathrm{FA}$ after the first cycle were $80 \%, 81 \%, 82 \%$, and $84 \%$ of the original compressive strength. This behavior can be attributed to the pozzolanic activity of fly ash and super fine red bricks powder, this leads to more bonding between the soil particles and the crushed brick particles and increase the residual compressive strength.

\subsection{Scanning Electron Microscopy}

Scanning electron microscopy (SEM) helps to understand the microstructure of rammed earth. The SEM images of the five mixtures at the curing age of 28 days are shown in Figure $9(\mathrm{a}-\mathrm{e})$. The maximum content of pores was observed in the mixture without stabilizer $(0 \% \mathrm{FA})$, whereas it is reduced in the mixtures containing fly ash. In Figure 9 (a) for the sample of $0 \% \mathrm{FA}$, the presence of excessive and large pores is responsible for low compressive strength and high linear shrinkage. As shown in Figure 9 (b-e), the microstructure of the mixtures with $5 \%, 10 \%, 15 \%$, and $20 \%$ fly ash change from large pores to small and homogeneous pores as the percentage of FA increases. Fly ash and super fine bricks particles gave a reduction of the total pore volume of mixtures due to the high pozzolanic reaction and filler effect, thereby providing less porosity, less dry shrinkage, and increase the compressive strength.
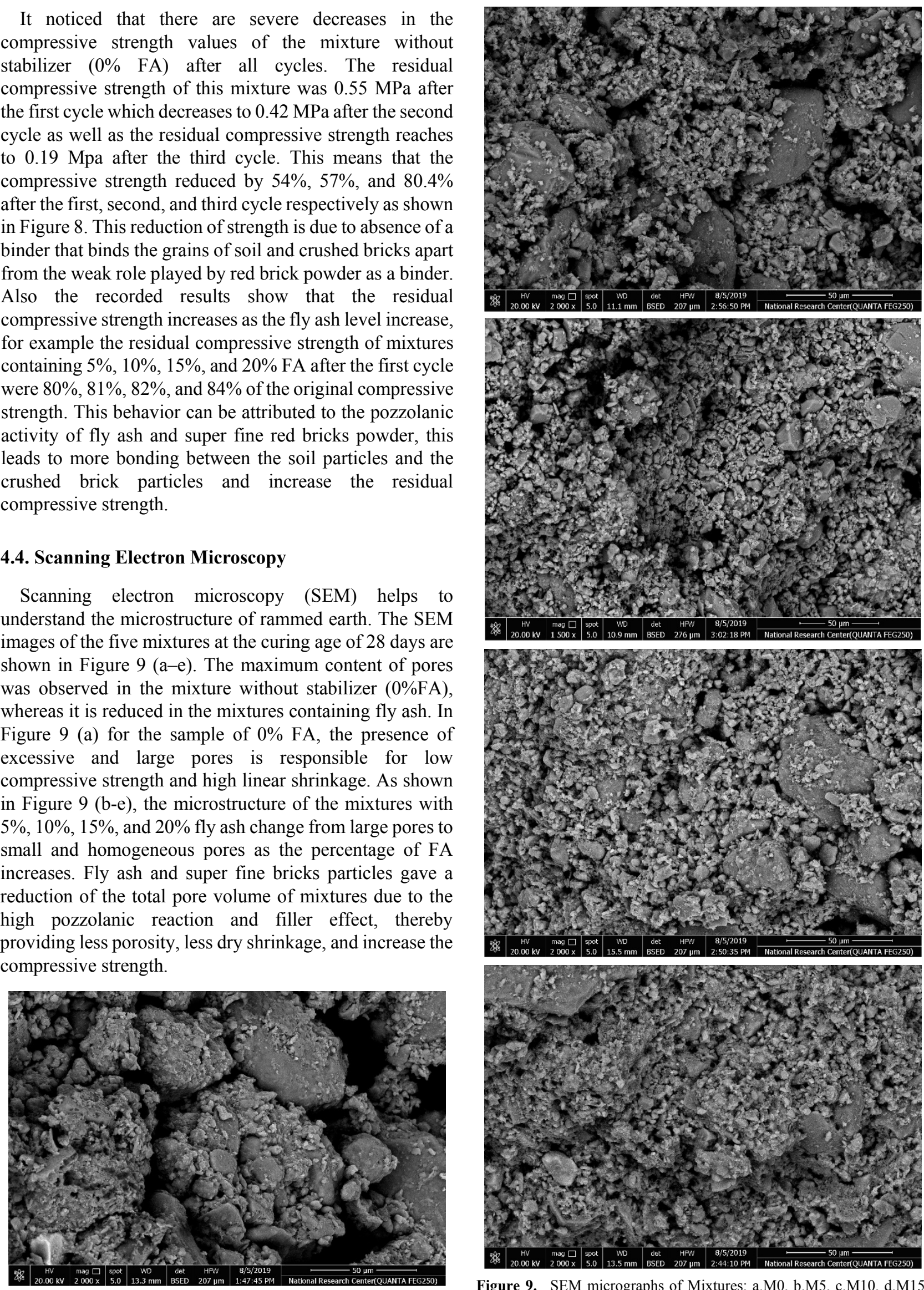

Figure 9. SEM micrographs of Mixtures; a.M0, b.M5, c.M10, d.M15 e.M20 


\section{Conclusions}

This study evaluates the utilization of solid industrial and building wastes such as soil excavation waste, red bricks waste, and fly ash as building materials accordingly, resource efficiency can be increased, and the environmental pollution by solid and greenhouse gases emissions will be reduced. Based on the obtained results, the next conclusions can be drawn:

1. Generally, the examined materials (soil excavation waste, red bricks waste, and fly ash) are suitable to use in rammed earth walls where the results related to compressive strength, linear shrinkage, and durability were complied with the standard requirements.

2. The mixture that consists of excavation soil waste and crushed red bricks without fly ash have the lower compressive strength where the strength generated mainly from the compacting of soil and the pozzolanic activity of a small amount of brick powder. Also, this mixture has the higher reduction in compressive strength after exposure to alternate cycles of wetting and drying.

3. In general, as the level of fly ash increases the compressive strength at all ages increases, moreover, all mixtures containing $5 \%, 10 \%, 15 \%$, and $20 \%$ of fly ash achieve the lower limit of compressive strength which stated by the standard requirements $(1.35 \mathrm{MPa})$ [47].

4. The linear shrinkage of mixtures depends on many factors such as the presence of clay and coarse particles, stabilizer type and amount, pore size and capillary water content, since the only variable in this study is the stabilizer level (FA), the results show that the mixture without stabilizer has the higher dry shrinkage of $0.42 \%$ at 56 days and this value decrease as the FA level increase and reach to $0.16 \%$ for $20 \%$ FA.

5. All mixtures have linear shrinkage complied with the standard requirement of linear shrinkage (0.5\%) [51].

6. The compressive strength reduction percentages due to wetting and drying cycles were decrease as FA level increase where it reaches to $84 \%$ for $0 \% \mathrm{FA}$, while it is equal to $37.3 \%$ for $20 \% \mathrm{FA}$.

7. It can be observed from the SEM that pore size decrease due to addition of $5 \%, 10 \%, 15 \%$, and $20 \%$ fly ash, which led to improve the strength and reduction in dry shrinkage as a result of filler and pozzolanic effect of FA.

\section{REFERENCES}

[1] R.M. Pulselli, E. Simoncini, F.M. Pulselli, S. Bastianoni. Energy analysis of building manufacturing, maintenance and use: building indices to evaluate housing sustainability, Energy and Buildings, Vol.39, No.5, pp.620-628, 2007.
[2] L.Pérez-Lombard, J. Ortiz, C. Pout. A review on buildings energy consumption information, Energy Build, Vol.40, pp. 394-398, 2008.

[3] J. Yudelson. The green building revolution. Washington, D.C.: Island Press, 2008.

[4] W. Haas, F. Krausmann, D. Wiedenhofer, M. Heinz. How circular is the Global Economy? An Assessment of Material Flows, Waste Production, and Recycling in the European Union and the World in 2005. J. Ind. Ecol., Vol.19, pp.765$777,2015$.

[5] Q.Liu, T. Tong, S. Liu, D. Yang, Q. Yu. Investigation of using hybrid recycled powder from demolished concrete solids and clay bricks as a pozzolanic supplement for cement, Constr. Build. Mater, Vol.73, pp.754-763, 2014.

[6] R.A. Robayo-Salazar, J.F. Rivera, R. Mejía de Gutiérrez. Alkali-activated building materials made with recycled construction and demolition wastes, Constr. Build. Mater, Vol.149, pp.130-138, 2017.

[7] Y. Miyatake. Technology development and sustainable construction, J. Manag. Eng., Vol.12, pp. 23-27, 1996.

[8] C.J. Kibert. Sustainable Construction: Green Building Design and Delivery, 4th ed., John Wiley and Sons, Inc.: Hoboken, NJ, USA, 2016.

[9] D. Leitão, D., J. Barbosa, E. Soares, T. Miranda, N. Cristelo, A. Briga-Sá. Thermal performance assessment of masonry made of ICEB's stabilized with alkali-activated fly ash, Energy Build, Vol.139, pp.44-52, 2017.

[10] M.B.Mansour, A.Jelidi, A.S. Cherif, S.B. Jabrallah. Optimizing thermal and mechanical performance of compressed earth blocks (CEB), Constr. Build. Mater. , Vol.104, pp.44-51, 2016.

[11] E. R. Andal, J. Berlin P. Juanzon. Identifying Risks in Implementing Sustainable Building Materials in Condominium Fit-out Projects Using Analytic Hierarchy Process, Civil Engineering and Architecture, Vol.8 (6), pp. 1266 - 1276, 2020. DOI: 10.13189/cea.2020.080610

[12] B.Chittoori, A.J. Puppala, R. Reddy, M. Marshall. Sustainable reutilization of excavated trench material, GeoCongress, pp.4280-4289, 2012.

[13] C.J.J. Eras, A.S. Gutierrez, D.H. Capote, L. Hens, C. Vandecasteele. Improving the environmental performance of an earthwork project using cleaner production strategies, J. Clean. Prod. Vol.47, pp.368-376, 2013.

[14] K.Voit, T. Zimmermann. Characteristics of selected concrete with tunnel excavation material, Construction and Building Materials, Vol. 101, pp.217-226, 2015.

[15] P. Priyadharshinia, K. Ramamurthya, R. G. Robinsonb. Sustainable reuse of excavation soil in cementitious composites, Journal of Cleaner Production, Vol.176, pp.999-1011, 2018.

[16] A. Dixit, H.Du, Pang. Marine clay in ultra-high performance concrete for filler substitution, Construction and Building Materials, Vol.263, No.120250, pp. 2020

[17] H.Böke, S. Akkurt, B. Ipeko` glu, E. U $\mathrm{U}^{\sim}$ gurlu. Characteristics of brick used as aggregate in historic brick-lime mortars and plasters, Cem. Concr. Res. Vol. 36, 
pp.1115-1122, 2006.

[18] T. Vieira, A. Alves, J. de Brito, J.R. Correia, R.V. Silva. Durability-related performance of concrete containing fine recycled aggregates from crushed bricks and sanitary ware, Mater. Des. Vol. 90, pp.767-776, 2016.

[19] A.A. Aliabdo, A. Abd-Elmoaty, H.H. Hassan. Utilization of crushed clay brick in concrete industry, Alexandria Eng. J., Vol.53, pp.151-168, 2014.

[20] J.Silva, J.D. Brito, R. Veiga. Incorporation of fine ceramics in mortars, Constr. Build. Mater., Vol. 23, pp.556-564, 2009.

[21] V. Letelier, J. Ortega, P. Muoz, E. Tarela, G. Moriconi. Influence of waste brick powder in the mechanical properties of recycled aggregate concrete, Sustainability, Vol.10, No. 4, pp.1037, 2018.

[22] J.C. Morel, A. Mesbah, M. Oggero, P. Walker. Building houses with local materials: means to drastically reduce the environmental impact of construction, Build Environ, Vol.36, pp.1119-26, 2001.

[23] G.Minke. Building with Earth-Design and Technology of a Sustainable Architecture, Birkhäuser Architecture, 2nd, rev. ed., 2006.

[24] I. Kenneth, A. Miller. Thermal behavior of an earth-sheltered autonomous building-The Brighton Earth ship, Renew Energy, Vol.34, pp.2037-2043, 2009.

[25] A. Gagliano, F. Patania, F. Nocera, C. Signorello. Assessment of the dynamic thermal performance of massive buildings, Energy Build, Vol.72, pp.361-370, 2014.

[26] L. Keefe. Earth building. Methods and materials, repair and conservation, Routledge, 2005.

[27] A.B. Ngowi. Improving the traditional earth construction: a case study of Botswana, Constr Build Mater, Vol.11, No.1, pp.1-7, 1997.

[28] P.A. Jaquin, C. Augarde .C.M. Gerrard .A chronological description of the spatial development of rammed earth techniques, Int J Archit Herit Vol. 2, pp.377-400, 2008.

[29] F.Pacheco-Torgal, S. Jalali. Earth construction: Lessons from the Past for Future Eco-efficient Construction, Construction and Building Materials, Vol.29, pp.512-519, 2012.

[30] L. Miccoli, U. Muller, P. Fontana. Mechanical Behavior of Earthen Materials: A Comparison between Earth Block Masonry, Rammed Earth and Cob, Construction and Building Materials, Vol.61, pp.327-339, 2014.

[31] Q. B. Bui, J. C. Morel, S. Hans, P. Walker. Effect of Moisture Content on the Mechanical Characteristics of Rammed Earth, Construction and Building Materials, Vol.54, pp.163-169, 2014.

[32] M. Sauer, O. Kapfinger Martine Rauch: Refined Earth Construction: Design with Rammed Earth, Munich, Germany, 2015.

[33] D. Ciancio, P. Jaquin, P. Walker. Advances on the Assessment of Soil Suitability for Rammed Earth, Construction and Building Materials, Vol.42, pp. 40-47, 2013.
[34] L. Miccoli, U.Muller, P. Fontana. Mechanical Behavior of Earthen Materials: A Comparison between Earth Block Masonry Rammed Earth and Cob, Construction and Building Materials, Vol.61, pp. 327-339, 2014.

[35] R. Illampas, I. Ioannis, D. C. Charmpis. Overview of the Pathology, Repair and Strengthening of Adobe Structures, International Journal of Architectural Heritage, Vol. 7,No.2, pp.165-188,2013.

[36] M.R. Hall, W. Swaney. European modern earth Construction In Modern Earth Buildings, Woodhead Publishing Limited: Cambridge, UK, pp. 650-687, 2012.

[37] H.Binici, O. Aksogan, T. Shah. Investigation of Fiber Reinforced Mud Brick as a Building Material, Construction and Building Materials, Vol.19,No. 4,pp.313-318,2005.

[38] A. Hasanbeigi, L. Price, E. Lin. Emerging energy-efficiency and $\mathrm{CO}_{2}$ emission-reduction technologies for cement and concrete production: A technical review, Renew. Sustain. Energy Rev, Vol.16, pp.6220-6238, 2012.

[39] B.V. Reddy, P.P. Kumar. Embodied energy in cement stabilized rammed earth walls, Energy Build, Vol.42, pp.380-385, 2010.

[40] A. Dahmen. Who's afraid of raw earth? Experimental wall in New England and the environmental cost of stabilization, In: Ciancio D, Beckett C (eds) Rammed earth construction. CRC Press, Baco Raton, pp. 85-88, 2015.

[41] O. Kapfinger, Sauer M (eds).Martin Rauch, refined earth: construction and design with rammed earth. Detail: Institute fur internationale Architektur-Dokumentation $\mathrm{GmbH} \& \mathrm{Co}$. KG, Munich, 2015.

[42] B.Windstorm, A. Schmidt. A report of contemporary rammed earth construction and research in North America, Sustainability, Vol.5, pp.400-416, 2013.

[43] M. Fagone, F. Loccarini, G. Ranocchiai. Strength evaluation of jute fabric for the reinforcement of rammed earth structures, Compos. Part B Eng. Vol. 113, pp.1-13, 2017.

[44] ASTM C1602 / C1602M-18, Standard Specification for Mixing Water Used in the Production of Hydraulic Cement Concrete, ASTM International, West Conshohocken, PA, 2018.

[45] PN-B-06714-23:1984: Kruszywa mineralne. Badania-Oznaczanie zmian Objetosciowych Metoda Amslera; Polish Committee for Standardization: Warsaw, Poland, 1984.

[46] ASTM D559 / D559M-15, Standard Test Methods for Wetting and Drying Compacted Soil-Cement Mixtures, ASTM International, West Conshohocken, PA, 2015.

[47] M. Hall, Y. Djerbib. Rammed Earth Sample Production: Context, Recommendations and Consistency, Construction and Building Materials, Vol.18, No.4, pp.281-286, 2004.

[48] V. Rigassi, CRATerre-EAG. Compressed Earth Blocks: Manual of Production, German Center for Development Technologies - GATE, Germany, Volume I, 1985.

[49] J. M. Ortega, V. Letelier, C. Solas, G. Moriconi, M. A. Climent, I. Sanchez. Long-term effects of waste brick powder addition in the microstructure and service properties of mortars, Construction and Building Materials, vol. 182, 
pp. 691-702, 2018

[50] J.E. Oh, Y. Jun, Y. Jeong. Characterization of geopolymers from compositionally and physically different Class F fly ashes, Cement and Concrete Composites.Vol.50 pp.16-26, 2014 .

[51] NZS 4297:1998. Engineering Design of Earth Buildings;
Standards New Zealand: Wellington, New Zealand, 1998.

[52] G. Maria Idália, G. Teresa, F. Paulina. Unstabilised Rammed Earth: Characterization of Material Collected from Old Constructions in South Portugal and Comparison to Normative Requirements, International Journal of Architectural Heritage, Taylor \& Francis, Vol.8, No.2, pp.185-212, 2014. 